\title{
Titanium Elastic Nails for Pediatric Femur Fractures: Clinical and Radiological Study
}

\author{
Nishikant Kumar*, Laljee Chaudhary \\ Department of Orthopaedics, Darbhanga medical College and Hospital, Laheriasarai, Bihar, India \\ E-mail: knishikant@ymail.com \\ Received May 16, 2010; accepted July 14, 2010
}

\begin{abstract}
Background: Management of fem oral diaphy seal fractures in the age group 6-16 years is controversial. There has been a resu rgence worldwide for operative fixation. Material and methods: Twenty children (15 boys, 5 girls) aged 6-16 years with femoral diaphyseal fractures (20 fractures, one in each) were stabilized with Titaniu m Elastic Nail (TEN). Pat ients underw ent su rgery within ten days of t heir in jury. The results were evaluated using Flynn's Scoring Criteria.Two nails were used in each fracture. Results: All 20 patients were available for evaluation and follow up for a m ean duration of 24 months (15-32 months). Radiological union in all cases was achieved in a mean time of 8 weeks. Full weight bearing was possible in a mean time of 10 weeks (8-12 weeks). The results were excellent in 14 patients (70\%) and successful in 6 patients $(30 \%)$. Few complications that occurred wer e infection (in 2 cases), knee joint stiffness(in 4 cases), angulation less than 10 degrees( in 4 cases), shortening less than $10 \mathrm{~mm}$ (in 4 cases). Conclusion: Intramedullary fixation by TEN is an effective treatment of fracture of femur in properly selected patients of the 6-16 years age group.
\end{abstract}

Keywords: Children, Intramedullary Fixation, Titanium Elastic Nail, Femoral Fracture, Diaphysis

\section{Introduction}

Femoral shaft fracture is an incapacitating injury in children $[1,2]$. The treatm ent $h$ as trad itionally been ag e related, influenced by the type of injury, associated injuries and the location and type of fracture.

The aim of fracture treatm ent is not only anatomical realignment, bu $t$ also restoration of $m$ uscle an $d$ joint function as close as possible to the normal. Psychological recovery is accelerated by early resumption of functional activity, which encourages healin $g$ of fract ure, maintenance of normal circulation, preservation of tone of the muscles and restoration of the movements of $t$ he joints. The aim there fore is ea rly mobilization by early use of the injured part without movement at the fracture site.

Because of rapid healing and spontaneous correction of angulations most of femoral shaft fractures in children younger than six y ears of a ge can be treated conservatively. Above six years of a ge all such fractures whe $\mathrm{n}$ treated non -operatively co uld $h$ ave lo ss o f reduction, malunion, intolerance and complication associ ated wi th plaster. Near the end of skeletal maturity accurate reduction is nece ssary as a ngular deformity is no 1 onger c orrectable by growth. In skeletally mature adolescents, use of an an tegrade solid locked intramedullary nail has be- come the standard of treatment.

In patients between 6-16 years of age there has been a tendency t owards operative approach. Ti tanium El astic Nailing (TEN) which is variously known as elastic stable intramedullary nailing (ESIN), has become the choice of stabilization in pediatric long bone fract ures, particularly the femoral shaft fracture. The present study is a imed at the ev aluation of in tramedullay fix ation with TEN in children with fe moral fractures. Until recently skeleta 1 traction and application of a cast was the preferre $d$ method o f t reatment of diaphyseal fem oral fract ures in children and young adolescent. The device would exploit a child's dense metaphyseal bone, rapid healing and ability to remodel without risking damage to the epiphysis or the blood supply to the capital femoral epiphysis.

\section{Material and Methods}

Twenty children ( 15 boys and 5 girls) in the age group of 6-16 years (average 10.8 years) with femoral shaft fracture were stab ilized with TEN from April 2007 to October 2009. The pre dominant mode of i njury was d ue to fall f rom hei ght ( $50 \%)$. $\mathrm{R}$ ight-sided i nvolvement was seen in 13 cas es $(65 \%)$ ) and left side in 7 cases $(35 \%)$. Mid-diaphyseal fracture of femur was found in $70 \%$ of 
cases and subtrochanteric fracture in $30 \%$ cases. About $50 \%$ of the patients underwent surgery within 10 days of their injury. The surgery had been carried out in the De partment of Orthopaedics, Darbhanga Medical College \& Hospital, Laheriasarai, Darbhanga, Bihar, India.

Nail comes in five diameters from $2.5 \mathrm{~mm}$ to $4.5 \mathrm{~mm}$ in a fixed length. The nails are colour coded for identification. The nails (Figure 1) are straight except for a bent tip. Sp ecial in struments in clude radiolucent redu ction tool, nail hol der, nail ben der, In sertion device, nai l extractor, wice grip and a nail impactor were used.

All th e $\mathrm{p}$ atients treated with TENs had skin/skeletal traction for approximately 1 week. As is the policy of our institution the traction pin $(4.76 \mathrm{~mm}$ threaded Steinmann Pin) was inserted in the operating room un der local anaesthesia. The Pin was i nserted in th e reg ion of tib ial tuberosity an terolateral to posteromedial $\mathrm{p}$ lane. So me patients were stabilised wit h sk in traction. Co mpound fractures were primarily thoroughly deb rided and upper tibial skeletal traction applied. The injured limb was put on a Bohler's-Brawn splint and adequate weight applied. This is essen tial to minimize $\mathrm{p}$ ain, $\mathrm{m}$ uscle $\mathrm{sp}$ asm an $\mathrm{d}$ shortening. App ropriate tetanus proph ylaxis, antibiotics and an algesics were i nstituted. In the period of rest and resuscitation, the patient was prop erly inv estigated and examined. As soon as the patient became fit for a naesthesia an $\mathrm{d}$ su rgery $\mathrm{h}$ e/she was po sted for fixation of femoral sh aft fr actures with TEN. Good pr eoperative X-ray (Figure 2) of the injured femur was u sed to estimate th e $n$ ail $d$ iameter an $d$ to de velop a $n$ approach to supplement fixation and plan the incision.

Half an hour before ope ration 1 ampoule of atropine was g iven i ntramuscularly. In travenous line was setup . Prophylactic an tibiotic $1 \mathrm{gm}$ ceftriax one was $\mathrm{g}$ iven intravenously. 1 am pule perinorm was given intramuscularly. Gene ral/spinal (a bove 14 y ears) a naesthesia was given with full asep tic and an tiseptic precautions on an image intensifier (IITV) compatible operation table.

As soon as anaesthesia was effective, the patient was placed supine and upper tibial skeletal traction pin was removed with aseptic and antiseptic precaution. The patient was placed on radiolucent fracture ta ble. The limb was prepared and draped to give access to the entire femur and knee joint and to permit manual manipulation of

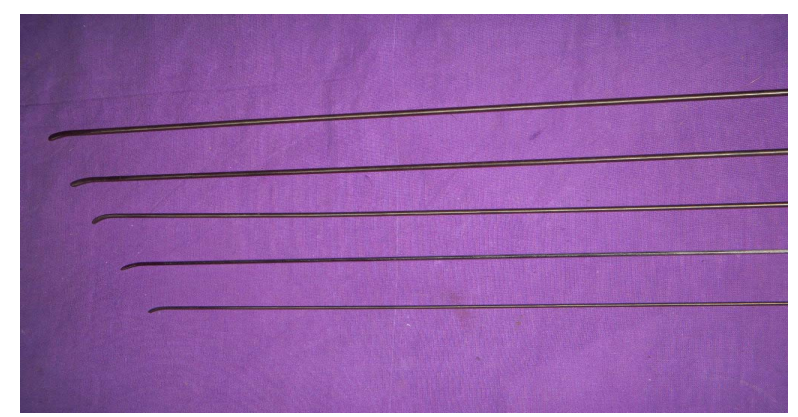

Figure 1. TEN with different length and diameter.
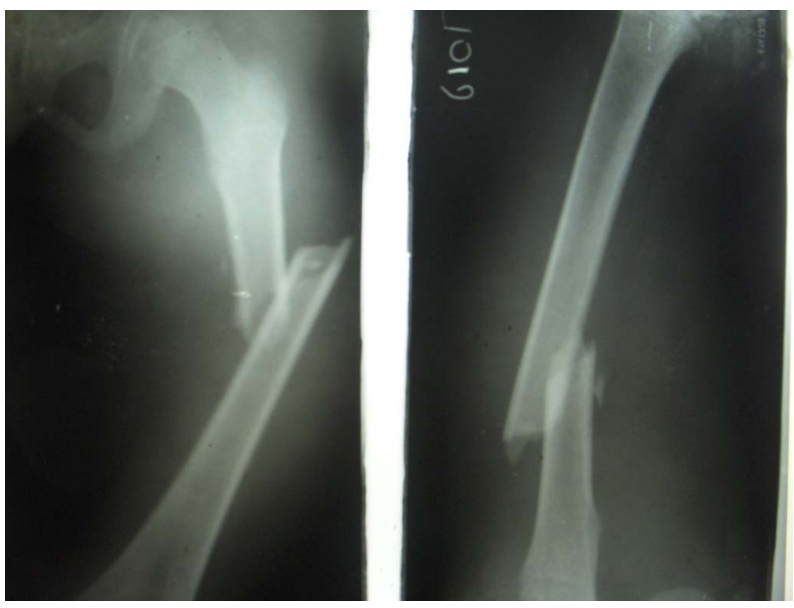

Figure 2. Preoperative x-ray of femur (AP and Lat view).

the thigh. The image in tensifier was $\mathrm{p}$ laced so that on $\mathrm{e}$ could get antero-posterior and lateral view of the femoral shaft. The monitor was placed in such a way that surgeon could have clear vision when inserting the nail and reducing the fracture.

The selection of the insertion point for the nails was medial and lateral at the top of the flare of the medial and lateral condyles so that after insertion they would tend to bind a gainst the flare of the condyles. If the nails are inserted t oo low, th ey will t end to backout, wh ich is a troublesome $\mathrm{c}$ omplication. In add ition, $\mathrm{t}$ he in sertion should be posterior to mid line of the shaft so that if the nails backout, they will be less lik ely to en ter the synovial pouch.

A $5 \mathrm{~mm}$ incision was made on the lateral side of the leg extending a bout $t$ wo finger breadth ab ove $t$ he s uperior pole of the Patella. (The superior pole of the $p$ atella lies slightly above the level of the physis). A gu ide wire for $6.5 \mathrm{~mm}$ cannulated scre w was pas sed at 45 degrees angulation at the level of the superior pole of the patella. Over this a drill hole was made with the cannulated drill bit. Usi ng a cur ved bo ne awl, $t$ he hole is ex tended cephalad to elongate the hole and avoid cracking of the cortex when the rod is inserted. The medial entry hole was si milarly el ongated using a $c$ urved $b$ one a wl i $n$ cephalad direction. The diameter of nail should be $2 / 5$ of the internal diameter of $\mathrm{t}$ he $\mathrm{m}$ edullary canal (Nail diameter $=0.4 \times$ Canal diameter).

Ideally, the lateral nail sho uld ex tend to t he lev el of the greater trochanter and the medial nail in to the femoral neck. The amount of prebending should be equal for both the nails. (The amount of bending should be three times the inner diameter of the shaft).Both the nails were inserted through the ent ry holes one a fter an other an $d$ were driven up to th e fracture site. Th e red uction was helped by the use of F-tool which is a radiolucent device. The arms of the F-tool were readjusted depending on the fracture configuration and bulk of thigh viewing with the image intensifier. This nail was advanced about $2 \mathrm{~cm}$ and 
then rotated. At this point, it was ad vanced further by rotating th is nail. Furth er red uction of the fract ure was accomplished and then the second nail was advanced.

The traction was released and bo th nails were advanced to their full leng th. Rotational and ang ular malreductions were che cked a nd if present $t$ he sam e was corrected by partially with drawing the nails, correcting the d eformity and rei nserting the $\mathrm{n}$ ails. When $\mathrm{t}$ he nail was at its final po sition, it was marked with a pen or clamp ab out 10 to $20 \mathrm{~mm}$ fro $\mathrm{m}$ the in sertion hole. The nails were cu t at the marked level and advanced so that they lay agai nst the s upracondylar flare of the femur in order to avoid complications at the insertion site.

A knee immobilizer or controlled motion brace should be used for additional support. The patients were advised to perform movements at th e kn ee joint and three point touch d own e xercise $t$ he day aft er su rgery un der the guidance of a physiotherapist. When early callus formation is observed, weight bearing can be increased. External support can be discontinued when radiographic healing is co mplete. It is im portant th at the patients bear weight because this provides the motion at the fracture site that leads to early callus formation. In all cases postoperative $\mathrm{x}$-rays an tero-posterior and lateral $\mathrm{v}$ iews were taken. In the post-operative period parenteral an tibiotics were continued for 5 days and then oral antibiotics were given till stitch removal. Along with an tibiotics, haematinics, serratiop eptidase, Calciu $\mathrm{m}$, multivitamins were given. Stitches were rem oved on the $12^{\text {th }}$ post-operative day. After remo val of stitch by $13^{\text {th }}$ to $14^{\text {th }}$ day post-operative patients were discharged.

Patients underwent regular follow up in the out patient department for clinical and radiological evaluation in the immediate post-operative period (Figure 3), at 4 weeks, 8 weeks (Figure 4), 12 weeks (Figure 5), 24 weeks, 35 weeks or till the publication of this series, whichever was earlier.

\section{Results}

The median duration of the surgery was $80 \min (60-120$ $\mathrm{min})$. All 20 patients were available for evaluation after a mean of 24 months (15-32 months) of follow-up. All patients were encoura ged to do hi $\mathrm{p}$ and $\mathrm{k}$ nee no nweight bearing exe rcises from first post-operative day. W eight bearing was allowed according to the fracture geography and fixation. At the end of $1^{\text {st }}$ post operative week all patients were made ambulatory on crutches allowing weight bearing according to the qua lity of fixation. By $8^{\text {th }}$ week all the patients were bearing weight with only 2 patients with touch-down weight bearing. Out of 20 cases, 2 cases complained of pain and irritation of sk in at the entry site, associated with the prominence of the ends of the nails.

Out of 20 cas es, $10 \mathrm{~m} \mathrm{~m}(1 \mathrm{~cm})$ short ening was observed in 4 cas es. These were among the earlier cases of the series and with comminuted fractures. Out of 20 pa- tients, 3 pat ients showed 10 degree or less angulation in the 1 ateral $\mathrm{pl}$ ane and o ne $\mathrm{p}$ atient had an eight degree angulation in the ant eroposterior plane. No broken nails were observed in any of the 20 cases. Out of 20 cases, 2 opening the entry site. These patients had to undergo knee physiotherapy again and regained movements at the knee. No re-fracture was observed in the 2 cases that underwent

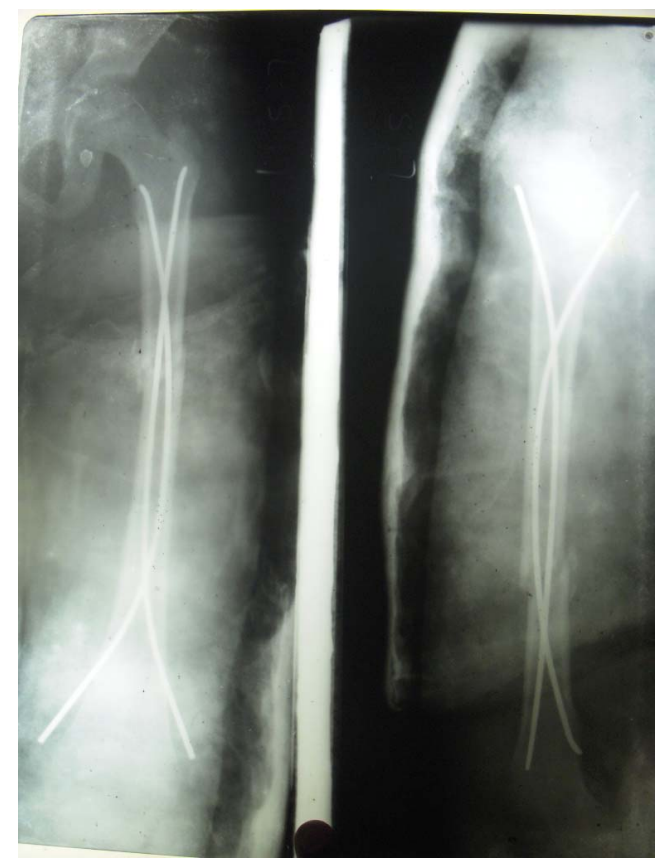

Figure 3. Immediate postoperative $x$-ray of femur (AP and Lat view).

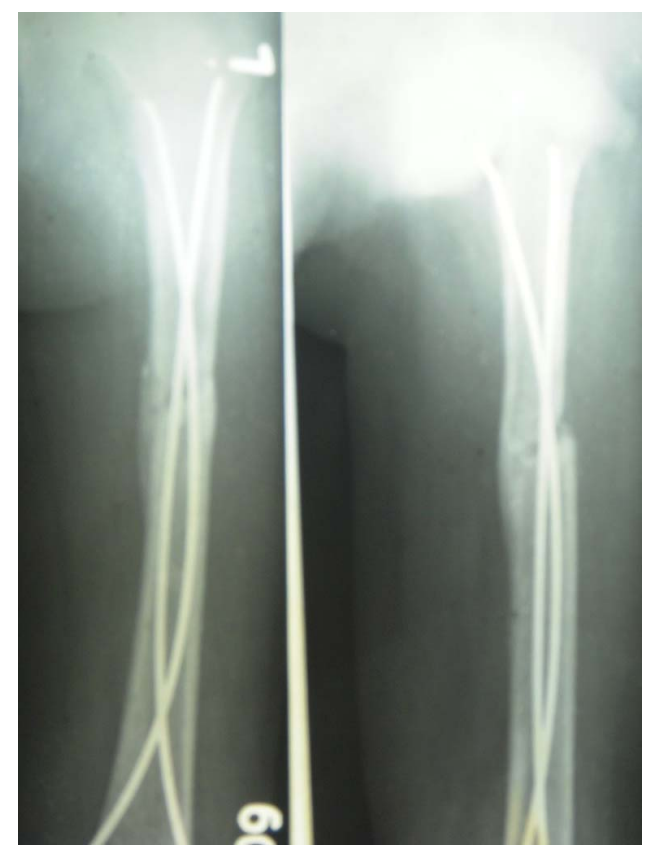

Figure $4.8^{\text {th }}$ week postoperative $x$-ray of femur (AP and Lat view). 


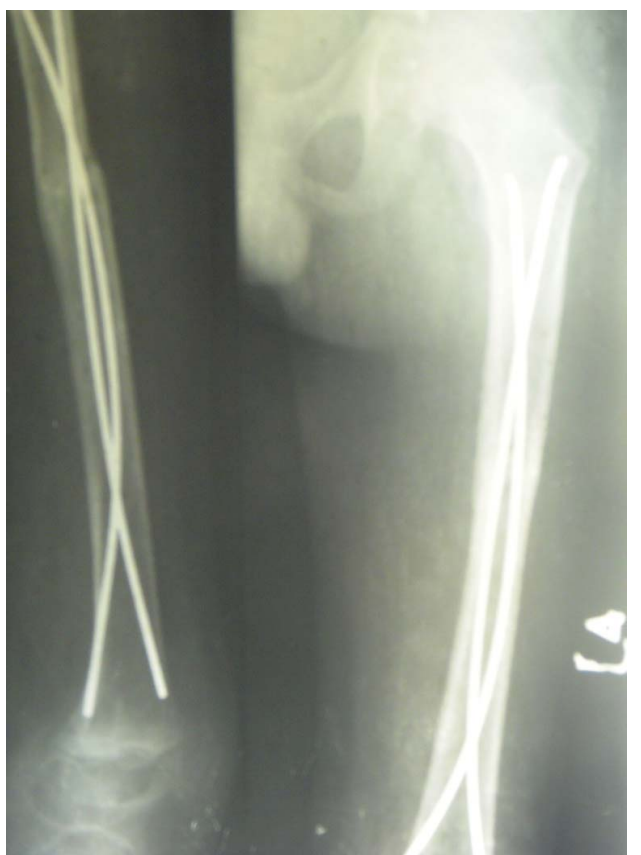

Figure 5. $12^{\text {th }}$ week postoperative $\mathrm{x}$-ray of femur (AP and Lat view).

nail removal.

\section{Discussion}

In the present series TEN was used as a mode of fixation in different types of femoral fractures in children between ages 6 to 16 years. 20 cases were treated a nd evaluated radiologically, clinically and functionally for the efficacy of TEN.In our series results were excellent in all 20 cases. Heinrich et al. (1994) reported that $22 \%$ of their patients had an ext ension over $5 \mathrm{~m} \mathrm{~m}$, and $11 \%$ had a shortening under $5 \mathrm{~m} \mathrm{~m}$. In a st udy com paring se veral methods including TEN t he maximum shortening was observed in the early casting group followed by external fixator group where as lengthening was observed only in the external fixator gr oup. In o ur st udy o nly 4 cases showed $1 \mathrm{~cm}$ shortening which was clinically indiscernible. Herndon et al. (1989) reported that malunion de veloped in seven of 24 patients who were $t$ reated wi th t raction while no malunion was observed in 21 children who were treated using TEN.

In a st udy co mparing ant erograde vers us ret rograde TEN by Galpin et al. [6] it was reported that 35 out of 37 patients had excel lent im provement in t erms of angul ar deformity. We had angulation less than 10 degree towards varus/valgus or antero/posterior only in 4 patients (20\%). In o ur seri es union pr ogressed sat isfactorily i n all 20 cases. At the end of 8 wee ks, 14 cases s howed fair to good cal lus formation while 6 cases had minimal call us formation. No bone grafting was requi red in any of $t$ he cases. No significant malunion was observed in any of the 20 patients.
Flynn et al. ( 2002) f ound TEN adva ntageous o ver hip-spica in treatment of fe moral shaft fractures in children. Buechsenschuetz et al. [7] documented TEN to be superior i $\mathrm{n}$ t erms of uni on, scar form ation and overal 1 patient satisfaction when compared to traction and casting. Ligier et al. [8] treated $123 \mathrm{fe}$ moral shaft fractures with TEN. All fract ures united with excel lent long term out come. Similarly Narayanan et al. (2004) found TEN to be a very $\mathrm{p}$ romising $\mathrm{m}$ odality of fracture $\mathrm{m}$ anagement i $\mathrm{n}$ children. In our series of 20 cases, in 2 cases im plants were removed after complete union.

In the present series, by the time stitches were removed all 20 cases could do straight leg raising exercises. At the end of study period 15 patients $(75 \%)$ could do full range of motion at knee joint.

All patients were encouraged to do hip and kn ee nonweight bearing exercises from first post-operative day. At the end of $1^{\text {st }}$ postoperative week all $p$ atients were $m$ ade ambulatory on crutches, allowing weight bea ring according to the quality of fixation.

Flynn et al. (2002) used a knee fixating device to control the pain, to support quadriceps and to prevent the end of nail cau sing any so ft tissue irritat ion in the knee until the callus tissu e appears (4-6 weeks). The patients were able to walk on day 9 on an av erage with the help of equipment an $\mathrm{d}$ at week 8.5 on avera ge wi thout the equipment. In our seri es patients were m ade ambulatory on crutches after $1{ }^{\text {st }}$ p ostoperative week. Partial weig ht bearing was al lowed at 6 weeks (ra nge 4-8 weeks) and full weight bearing was allowed at 10 weeks (Range 8-12 weeks).

The resu lts of th e p resent series are c omparable to those of the other series on management of femoral shaft fracture in chi ldren. It has definite a dvantages o ver the other co nventional i mplants that hav e bee $n$ use $d$ in the management of pediatric fractures. $\mathrm{N}$ otable ad vantages of this technique a re early union due to repeated micromotion at fracture site, early mobilization, early weight bearing, scar acceptance, eas y manipulation involved in implant rem oval and hi gh $\mathrm{p}$ atient sat isfaction rate. $\mathrm{B} \mathrm{e}-$ sides these, unlike other implants TEN does not endanger either the epiphysis or the blood supply to femoral head. The ex cellent biocompatibility and elasticity of titanium have further enhanced the virtues of TEN. High grade of elasticity of tit anium li mits the de gree and perm anence of de formation that the nail undergoes during insertion. More importantly elasticity promotes callus formation by limiting stress shielding.

Table 1 shows important aspects of th is study like age and sex of the patients, nature and mode of injury, specifications of nail $\mathrm{u}$ sed, fo llow up results an $\mathrm{d}$ du ration, surgical complications like intraoperative blood loss and others.

The bi omechanical pri nciple of TEN $\mathrm{i}$ s based on $\mathrm{t}$ he symmetrical bracing action of two elastic nails inse rted into the metaphysis, each of which bears against the inner bone at three points. This biomechanics helps in achie- 
Table 1.

\begin{tabular}{|c|c|c|c|c|c|c|c|c|c|c|c|c|c|c|}
\hline \multirow[b]{2}{*}{ S.No. } & \multirow[b]{2}{*}{ Name } & \multirow{2}{*}{$\begin{array}{c}\text { Age } \\
\text { in } \\
\text { years }\end{array}$} & \multirow[b]{2}{*}{ Sex } & \multirow{2}{*}{$\begin{array}{c}\text { Mode } \\
\text { of } \\
\text { Injury }\end{array}$} & \multirow{2}{*}{$\begin{array}{l}\text { Type of } \\
\text { fracture }\end{array}$} & \multirow{2}{*}{$\begin{array}{l}\text { Side of } \\
\text { fracture }\end{array}$} & \multirow{2}{*}{$\begin{array}{l}\text { Closed } \\
\text { /open } \\
\text { Injury }\end{array}$} & \multirow{2}{*}{$\begin{array}{c}\text { Blood } \\
\text { loss }\end{array}$} & \multirow{2}{*}{$\begin{array}{l}\text { Nail } \\
\text { dia. }\end{array}$} & \multirow[b]{2}{*}{ ROM } & \multicolumn{4}{|c|}{ Time for union } \\
\hline & & & & & & & & & & & $\begin{array}{c}4 \\
\text { Wks. }\end{array}$ & $\begin{array}{c}8 \\
\text { Wks. }\end{array}$ & $\begin{array}{c}12 \\
\text { Wks. }\end{array}$ & $\begin{array}{c}24 \\
\text { Wks. }\end{array}$ \\
\hline 1 & MP & 8 & $\mathrm{M}$ & RTA & MD & $\mathrm{R}$ & Closed & $100-200$ & $2.5 \mathrm{~mm}$ & FR & + & ++ & +++ & +++ \\
\hline 2 & RS & 11 & M & HGT & MD & $\mathrm{R}$ & Closed & $<100 \mathrm{ml}$ & $2.5 \mathrm{~mm}$ & FR & + & ++ & +++ & +++ \\
\hline 3 & NK & 13 & $\mathrm{M}$ & ASLT & MD & $\mathrm{L}$ & Closed & $100-200$ & $2.5 \mathrm{~mm}$ & FR & + & ++ & +++ & +++ \\
\hline 4 & PK & 12 & $\mathrm{~F}$ & RTA & ST & $\mathrm{R}$ & Open & $100-200$ & $2.5 \mathrm{~mm}$ & $0-100^{\circ}$ & - & + & ++ & ++ \\
\hline 5 & $\mathrm{GH}$ & 14 & $\mathrm{M}$ & HGT & MD & $\mathrm{L}$ & Closed & $<100 \mathrm{ml}$ & $3 \mathrm{~mm}$ & FR & + & ++ & +++ & +++ \\
\hline 6 & $\mathrm{KP}$ & 9 & $\mathrm{M}$ & ASLT & MD & $\mathrm{L}$ & Closed & $<100 \mathrm{ml}$ & $2.5 \mathrm{~mm}$ & FR & + & + & ++ & +++ \\
\hline 7 & ST & 11 & $\mathrm{M}$ & HGT & MD & $\mathrm{R}$ & Open & $200-300$ & $2.5 \mathrm{~mm}$ & FR & + & ++ & +++ & +++ \\
\hline 8 & $\mathrm{RD}$ & 14 & $\mathrm{~F}$ & ASLT & ST & $\mathrm{R}$ & Open & $<100 \mathrm{ml}$ & $3 \mathrm{~mm}$ & $0-120^{\circ}$ & + & ++ & +++ & +++ \\
\hline 9 & AK & 12 & $\mathrm{M}$ & HGT & MD & $\mathrm{R}$ & Closed & $100-200$ & $2.5 \mathrm{~mm}$ & FR & - & + & + & ++ \\
\hline 10 & UP & 13 & $\mathrm{M}$ & HGT & MD & $\mathrm{R}$ & Closed & $<100 \mathrm{ml}$ & $3 \mathrm{~mm}$ & FR & + & ++ & +++ & +++ \\
\hline 11 & BS & 10 & $\mathrm{~F}$ & RTA & ST & $\mathrm{L}$ & Closed & $100-200$ & $2.5 \mathrm{~mm}$ & FR & + & ++ & +++ & +++ \\
\hline 12 & DNP & 11 & $\mathrm{~F}$ & HGT & MD & $\mathrm{R}$ & Open & $200-300$ & $2.5 \mathrm{~mm}$ & $0-120^{\circ}$ & + & ++ & ++ & +++ \\
\hline 13 & BP & 11 & $\mathrm{M}$ & HGT & MD & $\mathrm{R}$ & Closed & $<100 \mathrm{ml}$ & $2.5 \mathrm{~mm}$ & FR & ++ & +++ & +++ & +++ \\
\hline 14 & NP & 15 & $\mathrm{M}$ & RTA & SY & $\mathrm{L}$ & Open & $100-200$ & $3 \mathrm{~mm}$ & FR & + & ++ & +++ & +++ \\
\hline 15 & WA & 16 & $\mathrm{M}$ & HGT & MD & $\mathrm{R}$ & Closed & $<100 \mathrm{ml}$ & $3.5 \mathrm{~mm}$ & FR & + & + & ++ & +++ \\
\hline 16 & SKG & 10 & $\mathrm{M}$ & HGT & ST & $\mathrm{L}$ & Open & $100-200$ & $2.5 \mathrm{~mm}$ & $0-100^{\circ}$ & + & ++ & +++ & +++ \\
\hline 17 & VD & 16 & $\mathrm{M}$ & HGT & MD & $\mathrm{L}$ & Closed & $<100 \mathrm{ml}$ & $3.5 \mathrm{~mm}$ & FR & + & + & ++ & ++ \\
\hline 18 & SL & 15 & $\mathrm{M}$ & RTA & ST & $\mathrm{R}$ & Closed & $<100 \mathrm{ml}$ & $3 \mathrm{~mm}$ & FR & + & ++ & +++ & +++ \\
\hline 19 & $\mathrm{AP}$ & 8 & $\mathrm{M}$ & ASLT & MD & $\mathrm{R}$ & Open & $200-300$ & $2.5 \mathrm{~mm}$ & $0-120^{\circ}$ & - & + & ++ & ++ \\
\hline 20 & GLY & 16 & $\mathrm{~F}$ & RTA & MD & $\mathrm{R}$ & Closed & $100-200$ & $3 \mathrm{~mm}$ & FR & ++ & +++ & +++ & +++ \\
\hline
\end{tabular}

$\mathrm{M}=$ Male; F = Female; RTA = Road Traffic Accident; HGT = Height; ASLT = Assault; MD = Mid diaphyseal; ST = Subtrochanteric; R = Right; L= Left; ROM = Range of Motion; FR = Full Range; + = Little amount callus seen; ++ = Fair amount callus seen; +++= Good amount of callus seen; - = No visible callus seen.

ving a high grade of stability i.e. flexural stability, axial stability, translational stability and rotational stability.

\section{Conclusions}

The i ntramedullary fix ation b y TEN is a m ethod of choice due to its distinct advantages over other c onventional modalities. Easy manoeuvering, excellent outcome, lower incide nce of $\mathrm{c}$ omplications a nd ea sier postopera tive $\mathrm{m}$ aintenance have $\mathrm{m}$ ade $\mathrm{T} \mathrm{EN} t$ he most pru dent, practical and successful intervention in the management of femoral shaft fractures of patients between 6 and 16 years of age.

\section{References}

[1] J. M. Flynn, D. Skaggs, P. D. Sponseller, T J. Ganley, R. M. Kay and K. K. Leitch, "The Operative Management of $\mathrm{P}$ ediatric F ractures of the Lower Extremity," The Journal of Bone and Joint Surgery, Vol. 84, No. 12, 2002, 2288-2300.

[2] M. Heybelly, H. H. Muratli, L. Celeb, S. Gulcek and A. Bicimoglu, "The Results of Intramedullary Fixation with Titanium Elast ic Nails in Ch ildren with Fem oral Fracture," Acta Orthop Traumatol Turc, Vol. 38, No. 3, 2004,
178-187.

[3] S. L. Bu ckley, "Current Tren ds in the Tr eatment of Femoral S haft Fractures in Children and Adol escents," Clinical Orthopaedics, Vol. 338, 1997, pp. 60-73.

[4] J. R. Kas ser and J. H. Be aty, "Femoral Shaft Fractures," In: J. H. Beaty, J. R. Kasser, Eds., Reckwood and Wilkins 'Fracture in Children", 5th Edition, Lippincott Williams and Wilkins, Philadelphia, 2001, pp. 941-980.

[5] J. M. Flynn, T. Hresko, R. A. Reynolds, R. D. Blasier, R. Davidson and J. Kasser, "Tita nium Elastic Na ils for Pediatric F emur F ractures: A M ulticenter S tudy of Ea rly Results with Analysis of Com plications," Journal of Pediatric Orthopaedics, Vol. 21, No. 1, 2001, pp. 4-8.

[6] R. D . G alpin, R. B . W illis an d N. Sabano , "Intramedullary Nailing of Pediatric Femoral Fractures," Journal of Pediatric Orthopaedics, Vol. 14, 1994, pp. 184-189.

[7] K. E. Buechsenschuetz, C. T. Mehlman, K. J. Shaw, A. H. Crawford and F. B. Immerman, "Femoral Shaft Fractures In Children: Traction and Casting Versus Casting Versus Elastic St able I ntramedullary Nailing," The Journal of Trauma, Vol. 53, No. 5, 2002, pp. 914-921.

[8] J. N. Ligier, J. P. Metaizeau, J. Prevot and P. Lascombes "Elastic Stable Intramedullary N ailing of Fem oral Shaft Fractures in Ch ildren," The Journal of Bone and Joint Surgery [Br], Vol. 70, No. 1, 1988, pp. 74-77. 